\title{
昇段・降段動作を考慮した歩行補助車の制動装置およびハンドグ リップとカゴの配置に関する理論的研究*
}

\begin{abstract}
The force that a user applies to a handgrip of a four-wheeled walker for step mounting and dismounting is estimated by a theoretical model derived from the equilibrium of the force and the moment in the sagittal plane. Effects of a breaking system and a position of a handgrip or a basket on the force estimated from the model are analyzed. If the breaking system can be used, the user operates the wheels easily only by the horizontal force applied to the handgrip anywhere the handgrip is positioned. If the breaking system cannot be used, it is impossible or difficult for the user to operate the wheels. The walker should be provided with a function that the user can use adequately the breaking system such as a handbrake during step mounting and dismounting. The force that the user applies to the handgrip depends on the horizontal position of the basket and not on the height. The basket should be positioned in the middle between the front and the rear wheels for the gravitational force of the baggage to be distributed evenly to the four wheels.
\end{abstract}

歩行補助車の車輪を段の上へ持ち上げたり段の下へ降ろしたりするために，使用者がハンドグリップへ加 える力を, 矢状面での力やモーメントの釣り合いから導出した力学モデルを用いて推定する. モデルの分析 結果から，制動装置の使用の影響およびハンドグリップやカゴの配置の影響について考察する。制動装置を 使用すれば，ハンドグリップをどこに配置しても，水平方向の力だけで車輪を容易に操作できる．制動装置 を使用しないと，車輪の操作が力学的に不可能になったり，困難になったりする．昇段および降段動作をす る際に，使用者がハンドブレーキなどの制動装置を適切に使用できるような機能を，歩行補助車に備える設 計が望ましい. カゴに荷物を載せる場合, 使用者がハンドグリップへ加える力は, カゴの水平方向の配置に 依存し, 高さには依存しない. 荷物に作用する重力が前後輪に均等に配分されるように, 前輪と後輪との中 間にカゴを配置するのが望ましい. (キーワード：モデル，段差，傾斜角，摩擦，設計）

\section{1.はじめに}

歩行補助車は, 自立歩行の可能な高齢者が, 外出の際 に歩行の補助や荷物の運搬や休息に用いる車輪が 4 輪以 上ある車である．歩行支援器具のひとつであり，製品安 全協会が品質や安全性に関する SG マーク認定基準を設 けている ${ }^{1)}$. 歩行補助車を設計する際には，その工学機 能と使用者の身体機能とを勘案する必要があるが, それ らの関係を人間工学の観点から分析した研究は少ない.

歩行補助車を利用する高齢者が対面する障壁のひとつ に，段差がある．国民生活センターは， $2 \mathrm{~cm}$ の段差でも， 歩行補助車で乗り越えることが困難な事例を報告してい $ろ^{2,3)}$. Eblen らは, 歩行補助車に類似した四輪歩行車を

\footnotetext{
*受付：2006 年 3 月 16 日 受理 : 2007 年 4 月 19 日

**神奈川大学工学部情報システム創成学科

Department of Information Systems Creation, Faculty of Engineering, Kanagawa University
}

使う高齢者を対象にした調査結果で，スロープを使わず に，歩行車で段差を降りる事例を報告している4). 歩行補 助車で段差を降りる動作も，使用者がバランスを崩しや すく, 乗り越える動作と同様に危険である. 本報では, 段 差を乗り越える動作と降りる動作とを対象として, 矢状 面での力やモーメントの釣り合いから，車輪を段の上へ 持ち上げたり段の下へ降ろしたりする際に，使用者が八 ンドグリップへ加える力を推定する.さらに，ハンドブ レーキなど制動装置の使用の影響，およびハンドグリッ プやカゴの配置の影響について理論的に分析する.

なお，段差を乗り越えたり降りたりする動作には，い くつかの方法が存在する. 本報では, それらの方法の中 で, 誰もが簡単にできる基本的な方法を対象とする. 段 差を乗り越える動作については，はじめに前輪を段の上 へ持ち上げてから, 次に後輪を持ち上げ，最後に使用者 が段差を昇る方法を対象とする. 段差を降りる動作につ いては, はじめに前輪を段の下に降ろしてから, 次に後 
輪を降ろし，最後に使用者が段差を降りる方法を対象と する、いずれの方法でも，車輪を段の上へ持ち上げたり 段の下へ降ろしたりする動作を，研究の対象とする。

\section{2. 歩行補助車へ作用する力の分析}

\section{2-1. 昇段時に前輪を持ち上げる動作}

四 1(a)に，段の上へ前輪を持ち上げる際に，歩行補助 車へ作用する力とトルクとを示す，歩行補助車は棒状で 一体式のハンドグリップおよび前輪と後輪とで構成され， それぞれが剛体で結合されている。 ハンドグリップは高 さが $H$ であり，後輪からの水平距離が $l_{h}$ である，高さ が $l_{c y}$ で後輪からの水平距離が $l_{c x}$ である歩行補助車の重 心には, 重力 $m g$ が作用する. 高さが $l_{b y}$ で後輪からの 水平距離が $l_{b x}$ であるカゴには, 質量 $M$ の荷物が積まれ

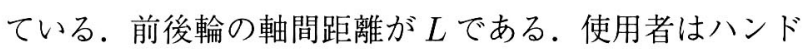
グリップを握り, 前輪を持ち上げようと, $F_{h x f_{m}}$ で手前 に引き $F_{h y f_{m}}$ で押し下げ，反時計回りのトルク $T_{h}$ を加 える，歩行補助車の重心とカゴに積んだ荷物とに作用す る重力に由来するモーメントと，ハンドグリップに作用 する力に由来するモーメントとが釣り合うと, 前輪が静 止する，その状態では，次式が成り立つ。

$$
\begin{aligned}
& F_{h x f_{m}}\left(H \cos \theta+l_{h} \sin \theta\right) \\
& -F_{h y f_{m}}\left(-H \sin \theta+l_{h} \cos \theta\right)+T_{h} \\
& -m g\left(l_{c x} \cos \theta-l_{c y} \sin \theta\right) \\
& -M g\left(l_{b x} \cos \theta-l_{b y} \sin \theta\right)=0
\end{aligned}
$$

ハンドブレーキなどの制動装置を使い，後輪と路面と の静止摩擦係数 $\mu$ が大きい条件では，ハンドグリップを 手前に引く力 $F_{h x f_{m}}$ だけで前輪を持ち上げられる。この 動作が可能な条件は, 式 (1) および後輪と路面との摩擦 の関係式から，

$$
\frac{C M_{f_{m}}+B G_{f_{m}}-T_{h}}{H D_{f_{m}}} \leq F_{h x f_{m}} \leq \mu(m+M) g(2)
$$

を満たす $F_{h x f_{m}}$ が存在することである. 但し, $H D_{f_{m}}$ と $C M_{f_{m}}$ と $B G_{f_{m}}$ とは, 式(3)〜式(5)に示すように，八 ンドグリップの配置と歩行補助車の重心とカゴに載せた 荷物とに由来する項である。

$$
\begin{aligned}
H D_{f_{m}} & =H \cos \theta+l_{h} \sin \theta \\
C M_{f_{m}} & =m g\left(l_{c x} \cos \theta-l_{c y} \sin \theta\right) \\
B G_{f_{m}} & =M g\left(l_{b x} \cos \theta-l_{b y} \sin \theta\right)
\end{aligned}
$$

制動装置を使わずに $\mu$ が小さい条件では, $F_{h x f_{m}}$ を強

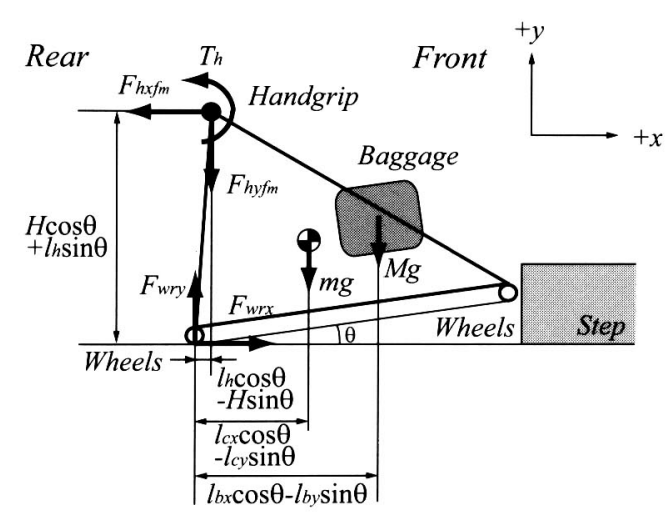

(a) 前輪を持ち上げる場合

(a) Lift up front wheels

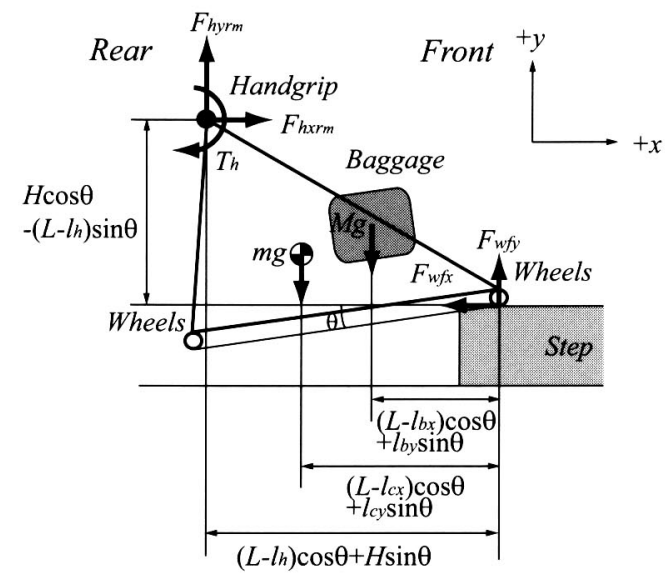

(b) 後輪を持ち上げる場合

(b) Lift up rear wheels

図 1 昇段時に歩行補助車へ作用する力とトルク．

Fig. 1 Force and torque applied to walker during step mounting.

くして最大静止摩擦力を超えると, 後輪が動き出して, 前 輪を持ち上げられない，そのような条件下で，かつ $T_{h}$ を 強くできないと，ハンドグリップを押し下げて，後輪と 路面との最大静止摩擦力を大きくし，ハンドグリップを 手前に強く引く操作方法を取らざるを得ない. $F_{h x f_{m}}$ を 強くしても後輪が動き出さない限界

$$
F_{h x f_{m}}=\mu\left(m g+M g+F_{h y f_{m}}\right)
$$

を式(1)に代入すると, ハンドグリップを押し下げる力が

$$
F_{h y f_{m}}=\frac{C M_{f_{m}}^{\prime}+B G_{f_{m}}^{\prime}-T_{h}}{-l_{h} \cos \theta+H \sin \theta+\mu H D_{f_{m}}}
$$

よりも強いと, 前輪を持ち上げ可能である. 但し, $C M_{f_{m}}^{\prime}$ と $B G_{f_{m}}^{\prime}$ とは，それぞれ

$$
\begin{aligned}
C M_{f_{m}}^{\prime}= & m g\left(l_{c x} \cos \theta-l_{c y} \sin \theta\right. \\
& \left.-\mu H D_{f_{m}}\right) \\
B G_{f_{m}}^{\prime}= & M g\left(l_{b x} \cos \theta-l_{b y} \sin \theta\right. \\
& \left.-\mu H D_{f_{m}}\right)
\end{aligned}
$$


である。

\section{2-2. 昇段時に後輪を持ち上げる動作}

図1(b)に, 段の上へ後輪を持ち上げる際に, 歩行補助 車へ作用するカとトルクとを示す．ハンドグリップや車 輪などの配置は, 前輪を持ち上げる動作のモデルと同様 である，使用者はハンドグリップを握り，後輪を持ち上 げようと, $F_{h x r_{m}}$ で奥に押し $F_{h y r_{m}}$ で引き上げ, 時計回 りのトルク $T_{h}$ を加える. 歩行補助車の重心とカゴに積 んだ荷物とに作用する重力に由来するモーメントと, 八 ンドグリップに作用する力に由来するモーメントとが鈞 り合うと，後輪が静止する。そその状態では，次式が成り 立つ.

$$
\begin{aligned}
& -F_{h x r_{m}}\left\{H \cos \theta-\left(L-l_{h}\right) \sin \theta\right\} \\
& -F_{h y r_{m}}\left\{H \sin \theta+\left(L-l_{h}\right) \cos \theta\right\}-T_{h} \\
& +m g\left\{\left(L-l_{c x}\right) \cos \theta+l_{c y} \sin \theta\right\} \\
& +M g\left\{\left(L-l_{b x}\right) \cos \theta+l_{b y} \sin \theta\right\}=0
\end{aligned}
$$

$\mu$ が大きい条件では, ハンドグリップを奥に押す力 $F_{h x r_{m}}$ だけで後輪を持ち上げられる。この動作が可能な条件は, 式 (10) および前輪と路面との摩擦の関係式から,

$$
\frac{C M_{r_{m}}+B G_{r_{m}}-T_{h}}{H D_{r_{m}}} \leq F_{h x r_{m}} \leq \mu(m+M) g(11)
$$

を満たす $F_{h x r_{m}}$ が存在することである. 但し,

$$
\begin{aligned}
H D_{r_{m}} & =H \cos \theta-\left(L-l_{h}\right) \sin \theta \\
C M_{r_{m}} & =m g\left\{\left(L-l_{c x}\right) \cos \theta+l_{c y} \sin \theta\right\} \\
B G_{r_{m}} & =M g\left\{\left(L-l_{b x}\right) \cos \theta+l_{b y} \sin \theta\right\}
\end{aligned}
$$

である。

$\mu$ が小さい条件では， $F_{h x r_{m}}$ を強くすると前輪が動き 出してしまうため, ハンドグリップを引き上げなければな らない. $F_{h x r_{m}}$ を強くしても前輪が動き出さない限界は

$$
F_{h x r_{m}}=\mu\left(m g+M g-F_{h y r_{m}}\right)
$$

である. 但し, $m g+M g<F_{h y r_{m}}$ であると, 前輪の垂 直荷重がゼロとなり持ち上がってしまうため，この場合 には基本的な方法で後輪持ち上げができないとする. 式 (15) を式 (10) に代入すると, ハンドグリップを引き上げ る力が

$$
F_{h y r_{m}}=\frac{C M_{r_{m}}^{\prime}+B G_{r_{m}}^{\prime}-T_{h}}{\left(L-l_{h}\right) \cos \theta+H \sin \theta-\mu H D_{r_{m}}}
$$

よりも強いと, 後輪を持ち上げ可能である. 但し,

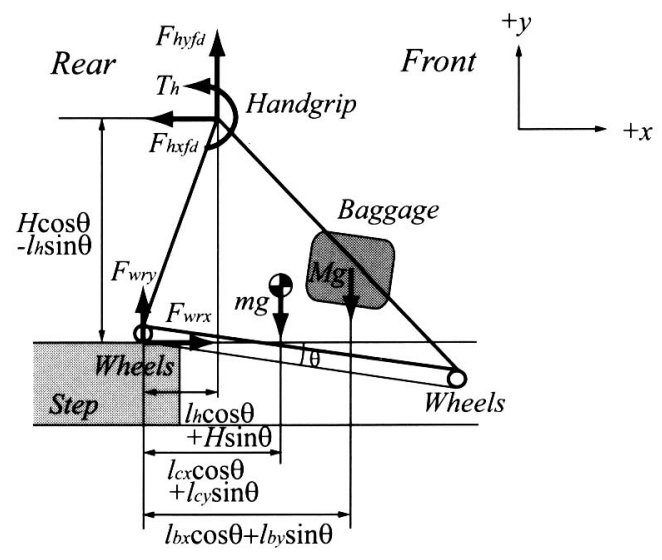

(a) 前輪を降万す場合

(a) Lift down front wheels

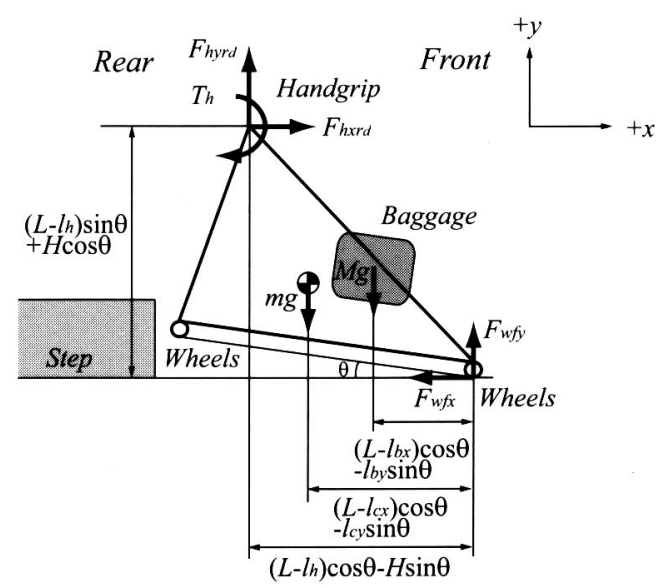

(b) 後輪を降万す場合

(b) Lift down rear wheels

図 2 降段時に歩行補助車へ作用する力とトルク.

Fig. 2 Force and torque applied to walker during step dismounting.

$$
\begin{aligned}
C M_{r_{m}}^{\prime}= & m g\left\{\left(L-l_{c x}\right) \cos \theta+l_{c y} \sin \theta\right. \\
& \left.-\mu H D_{r_{m}}\right\} \\
B G_{r_{m}}^{\prime}= & M g\left\{\left(L-l_{b x}\right) \cos \theta+l_{b y} \sin \theta\right. \\
& \left.-\mu H D_{r_{m}}\right\}
\end{aligned}
$$

である。

\section{2-3. 降段時に前輪を降ろす動作}

図 2(a)に，段の下へ前輪を降万す際に，歩行補助車へ 作用する力とトルクとを示す．段差を降りようと使用者 が上段より前に前輪を移動させると, 歩行補助車の重心 とカゴに積んだ荷物とに作用する重力のために，後輪を 中心として, 前輪を下げる方向にモーメントが作用する. 安全に段差を降りられるように，使用者はハンドグリッ プを $F_{h x f_{d}}$ の力で手前に引いたり， $F_{h y f_{d}}$ の力で引き上 げたり，反時計回りのトルク $T_{h}$ を加えたりする，重力 
によるモーメントとハンドグリップに作用する力による モーメントとが釣り合うと，前輪が静止する，その状態 では，次式が成り立つ。

$$
\begin{aligned}
& F_{h x f_{d}}\left(H \cos \theta-l_{h} \sin \theta\right) \\
& +F_{h y f_{d}}\left(H \sin \theta+l_{h} \cos \theta\right)+T_{h} \\
& -m g\left(l_{c x} \cos \theta+l_{c y} \sin \theta\right) \\
& -M g\left(l_{b x} \cos \theta+l_{b y} \sin \theta\right)=0
\end{aligned}
$$

$\mu$ が大きい条件では, 式 (19) および後輪と路面との摩 擦の関係式から,

$$
\frac{C M_{f_{d}}+B G_{f_{d}}-T_{h}}{H D_{f_{d}}} \leq F_{h x f_{d}} \leq \mu(m+M) g(20)
$$

を満たす $F_{h x f_{d}}$ が存在すれば，ハンドグリップを手前に 引くだけで，後輪を固定した状態で前輪を降ろすことが 可能である。但し，

$$
\begin{aligned}
& H D_{f_{d}}=H \cos \theta-l_{h} \sin \theta \\
& C M_{f_{d}}=m g\left(l_{c x} \cos \theta+l_{c y} \sin \theta\right) \\
& B G_{f_{d}}=M g\left(l_{b x} \cos \theta+l_{b y} \sin \theta\right)
\end{aligned}
$$

である.

$\mu$ が小さい条件では， $F_{h x f_{d}}$ を強くすると後輪が動き 出してしまうため, ハンドグリップを引き上げる必要が ある. $F_{h x f_{d}}$ を強くしても後輪が動き出さない限界は

$$
F_{h x f_{d}}=\mu\left(m g+M g-F_{h y f_{d}}\right)
$$

である. 但し, $m g+M g<F_{h y f_{d}}$ であると, 後輪の垂 直荷重がゼロとなり持ち上がってしまうため，この場合 には基本的な方法で前輪を降万す動作ができないとする. 式 (24) を式 (19) に代入すると, ハンドグリップを引き 上げる力が

$$
F_{h y f_{d}}=\frac{C M_{f_{d}}^{\prime}+B G_{f_{d}}^{\prime}-T_{h}}{l_{h} \cos \theta+H \sin \theta-\mu H D_{f_{d}}}
$$

よりも弱いと, 前輪が下へ動き出す. 但し,

$$
\begin{aligned}
C M_{f_{d}}^{\prime}= & m g\left(l_{c x} \cos \theta+l_{c y} \sin \theta\right. \\
& \left.-\mu H D_{f_{d}}\right) \\
B G_{f_{d}}^{\prime}= & M g\left(l_{b x} \cos \theta+l_{b y} \sin \theta\right. \\
& \left.-\mu H D_{f_{d}}\right)
\end{aligned}
$$

である。

\section{2-4. 降段時に後輪を降ろす動作}

図 2(b)に，段の下へ後輪を降乃す際に，歩行補助車へ 作用する力とトルクとを示す. 段差を降りょうと使用者
が上段より前に後輪を移動させると, 歩行補助車の重心 とカゴに積んだ荷物とに作用する重力のために，前輪を 中心として, 後輪を下げる方向にモーメントが作用する. 安全に段差を降りられるように，使用者はハンドグリッ プを $F_{h x r_{d}}$ の力で奥に押したり， $F_{h y r_{d}}$ の力で引き上げ たり，時計回りのトルク $T_{h}$ を加えたりする. 重力によ るモーメントとハンドグリップに作用する力によるモー メントとが釣り合うと, 前輪が静止する. その状態では, 次式が成り立つ。

$$
\begin{aligned}
& -F_{h x r_{d}}\left\{H \cos \theta+\left(L-l_{h}\right) \sin \theta\right\} \\
& -F_{h y r_{d}}\left\{-H \sin \theta+\left(L-l_{h}\right) \cos \theta\right\}-T_{h} \\
& +m g\left\{\left(L-l_{c x}\right) \cos \theta-l_{c y} \sin \theta\right\} \\
& +M g\left\{\left(L-l_{b x}\right) \cos \theta-l_{b y} \sin \theta\right\}=0
\end{aligned}
$$

$\mu$ が大きい条件では, 式 (28) および前輪と路面との摩 擦の関係式から,

$$
\frac{C M_{r_{d}}+B G_{r_{d}}-T_{h}}{H D_{r_{d}}} \leq F_{h x r_{d}} \leq \mu(m+M) g(29)
$$

を満たす $F_{h x r_{d}}$ が存在すれば，ハンドグリップを奥に押 すだけで，前輪を固定した状態で後輪を降ろすことが可 能である。但し,

$$
\begin{aligned}
& H D_{r_{d}}=H \cos \theta+\left(L-l_{h}\right) \sin \theta \\
& C M_{r_{d}}=m g\left\{\left(L-l_{c x}\right) \cos \theta-l_{c y} \sin \theta\right\} \\
& B G_{r_{d}}=M g\left\{\left(L-l_{b x}\right) \cos \theta-l_{b y} \sin \theta\right\}
\end{aligned}
$$

である。

$\mu$ が小さい条件では， $F_{h x r_{d}}$ を強くすると前輪が動き 出してしまうため, ハンドグリップを引き上げる必要が ある. $F_{h x r_{d}}$ を強くしても前輪が動き出さない限界は

$$
F_{h x r_{d}}=\mu\left(m g+M g-F_{h y r_{d}}\right)
$$

である，但し， $m g+M g<F_{h y r_{d}}$ であると，前輪の垂直 荷重がゼロとなり持ち上がってしまうため，この場合に は後輪を降乃す動作ができないとする，式 (33)を式 (28) に代入すると，ハンドグリップを引き上げるカが

$$
F_{h y r_{d}}=\frac{C M_{r_{d}}^{\prime}+B G_{r_{d}}^{\prime}-T_{h}}{\left(L-l_{h}\right) \cos \theta-H \sin \theta-\mu H D_{r_{d}}}
$$

よりも弱いと，後輪が下へ動き出す。但し，

$$
\begin{aligned}
C M_{r_{d}}^{\prime}= & m g\left\{\left(L-l_{c x}\right) \cos \theta-l_{c y} \sin \theta\right. \\
& \left.\left.-\mu H D_{r_{d}}\right)\right\} \\
B G_{r_{d}}^{\prime}= & M g\left\{\left(L-l_{b x}\right) \cos \theta-l_{b y} \sin \theta\right. \\
& \left.\left.-\mu H D_{r_{d}}\right)\right\}
\end{aligned}
$$

である。 
表 1 歩行補助車のパラメー夕.

Tab. 1 Parameters of four-wheeled walker.

\begin{tabular}{|c|c|}
\hline 質量 $m(\mathrm{~kg})$ & 5.6 \\
\hline 車軸間距離 $L(\mathrm{~m})$ & 0.59 \\
\hline ハンドグリップの高さ $H(\mathrm{~m})$ & 0.87 \\
\hline 後輪からハンドグリップまでの水平距離 $l_{h}(\mathrm{~m})$ & 0.0 \\
\hline 後輪から重心までの水平距離 $l_{c x}(\mathrm{~m})$ & 0.30 \\
\hline 重心の高さ $l_{c y}(\mathrm{~m})$ & 0.44 \\
\hline 後輪からカゴまでの水平距離 $l_{b x}(\mathrm{~m})$ & 0.44 \\
\hline カゴの高さ $l_{b y}(\mathrm{~m})$ & 0.44 \\
\hline
\end{tabular}

\section{2-5. パラメータの設定}

歩行補助車のパラメータ值を, 表 1 に示す.これらの中 で質量 $m$ と車軸間距離 $L$ とハンドグリップの高さ $H$ に ついては, 現在市販されている歩行補助車の值をもとに 決定した.テクノエイド協会が発行する福祉用具総覧に 製品が掲載されているメーカが販売する歩行補助車の質 量, 奥行き, 高さを調査した ${ }^{5)}$. その結果, 質量は $2.9 〜$ $10.6[\mathrm{~kg}]$, 奥行きは $0.49 \sim 0.69[\mathrm{~m}]$ であった. 高さにつ いては, ハンドグリップ高が可変であることから, 最低 值と最高值が存在する. 高さの最低値は $0.72 \sim 0.89[\mathrm{~m}]$, 最高值は $0.83 \sim 1.00[\mathrm{~m}]$ であった. 本研究では平均的な 歩行補助車を想定して, 分布の平均值を用い, 表 1 のよ うに設定した. また，多くの歩行補助車のハンドグリップ は後輪の近傍に配置されていることから, 後輪の真上に ハンドグリップが配置されている場合を想定した．重心 については, 歩行補助車の中心に配置した. カゴの高さ については, 重心と同じ位置に配置した. カゴの水平距 離については, 市販の歩行補助車は歩行動作を妨げない ように前方にカゴが配置されていることを踏まえて, 後 輪からの距離が車軸間距離の $75 \%$ とした。

ハンドグリップ周りのトルク $T_{h}$ については, 製品評 価技術基盤機構が公表している手関節の最大関節内トル クを用いて, 65 歳以上の高齢者の平均值 $T_{h}=7.3[\mathrm{Nm}]$ とした6).

\section{3. 結 果}

\section{3-1. 傾斜角と静止摩擦係数の分析}

日常生活で対面する段差は最高でも $0.1[\mathrm{~m}]$ 程度であ り，パラメータの設定で述べたように，市販されている 歩行補助車の奥行きは $0.49 \sim 0.69[\mathrm{~m}]$ である. そのため, 傾斜角 $\theta$ の範囲を $0.0 \sim 15.0[\mathrm{deg}]$ とする. カゴには荷物 を積んでいないと仮定し， $M=0.0[\mathrm{~kg}]$ とする．車輪と 路面との静止摩擦係数 $\mu$ については, 制動装置の使用の
有無を想定して決定した。制動装置を使用しないと，こ ろがり摩擦で $\mu$ は小さいが, 使用すると，すべり摩擦と なり $\mu$ は大きい．低速かつ路面が乾燥している状態での すべり摩擦係数は $0.7 \sim 0.9$ 程度であることから ${ }^{7)}, \mu$ の 範囲を $0.0 〜 1.0$ と設定した。

図 3 に結果を示す. $\mu$ により歩行補助車の制御方法が変 わることがわかる．制動装置を使い $\mu$ が大きく，式 (2), (11), (20), (29) の各条件を満たす力が存在する場合には, ハンドグリップを手前に引いたり奥へ押したりする水平 方向の力だけで，車輪を操作できる. 水平方向の力はあ る範囲を持つが, 図 3 では式 (2), (11), (20), (29) の下 限值を示した，昇段と降段，操作する車輪，傾斜角によ り傾向は変化するが，いずれの動作でも $\mu$ が 0.4 以上あ れば，水平方向の力だけで車輪を操作できる，その力は， 最大でも $21.1[\mathrm{~N}]$ あれば良い.この結果から, 制動装置 を適切に使用して， $\mu$ を大きくできれば，使用者は容易 に車輪を持ち上げたり降ろしたりできることがわかる。

しかし図 3 からは， $\mu$ が小さくなると，水平方向の力 だけでなく，ハンドグリップを引き上げたり押し下げた りする垂直方向の力も加えなければ，車輪を操作できな いこともわかる. 式 (2), (11), (20), (29) からわかるよう に， $\mu$ が小さいと水平方向の力を強くできないため, 式 (1), (10), (19), (28) において, 車輪を操作するための モーメントが不足する。それを補うために，ハンドグリッ プへ垂直方向にも力を加える必要がある．さらに，前輪 に関する動作については， $\mu$ が小さいと，車輪の操作が力 学的に不可能となることもわかる. 分析の結果から, こ の原因として，4つのケースが存在することがわかった. 第一は, 式 (7) や式 (25) の分母がゼロとなる特異点で, $F_{h y f m}$ や $F_{h y f d}$ が無限大となるため, 前輪を操作できな い. 第二は, 静止摩擦係数 $\mu$ が小さいために, 式 (7) や式 (25) の分母が負となるケースで, $F_{h y f m}$ や $F_{h y f d}$ が負 となり，前輪を操作できない．第三は， $F_{h y f m} や F_{h y f d}$ が人間の最大発揮力を超えるケースである．図 3 では， $F_{\text {hyfm }}$ や $F_{\text {hyfd }}$ が $100[\mathrm{~N}]$ を超えたときを，このケース とした．第四は，接地している車輪の垂直荷重がゼロと なり持ち上がってしまうケースである.

図 3(a) に示す昇段時に前輪を持ち上げる動作について は, 第一と第三のケースが原因で，前輪持ち上げ不可能 になることがあった．さらにその近辺では，前輪を持ち 上げる動作が力学的に可能であっても，ハンドグリップ を強く押し下げる必要がある．前輪持ち上げが不可能な 領域は， $\theta$ が小さいときに見られ， $\theta$ が大きくなると消 失した. 後輪の真上にハンドグリップが配置されている $\left(l_{h}=0.0[\mathrm{~m}]\right)$ ので, $\theta$ が大きくなるとハンドグリップが 

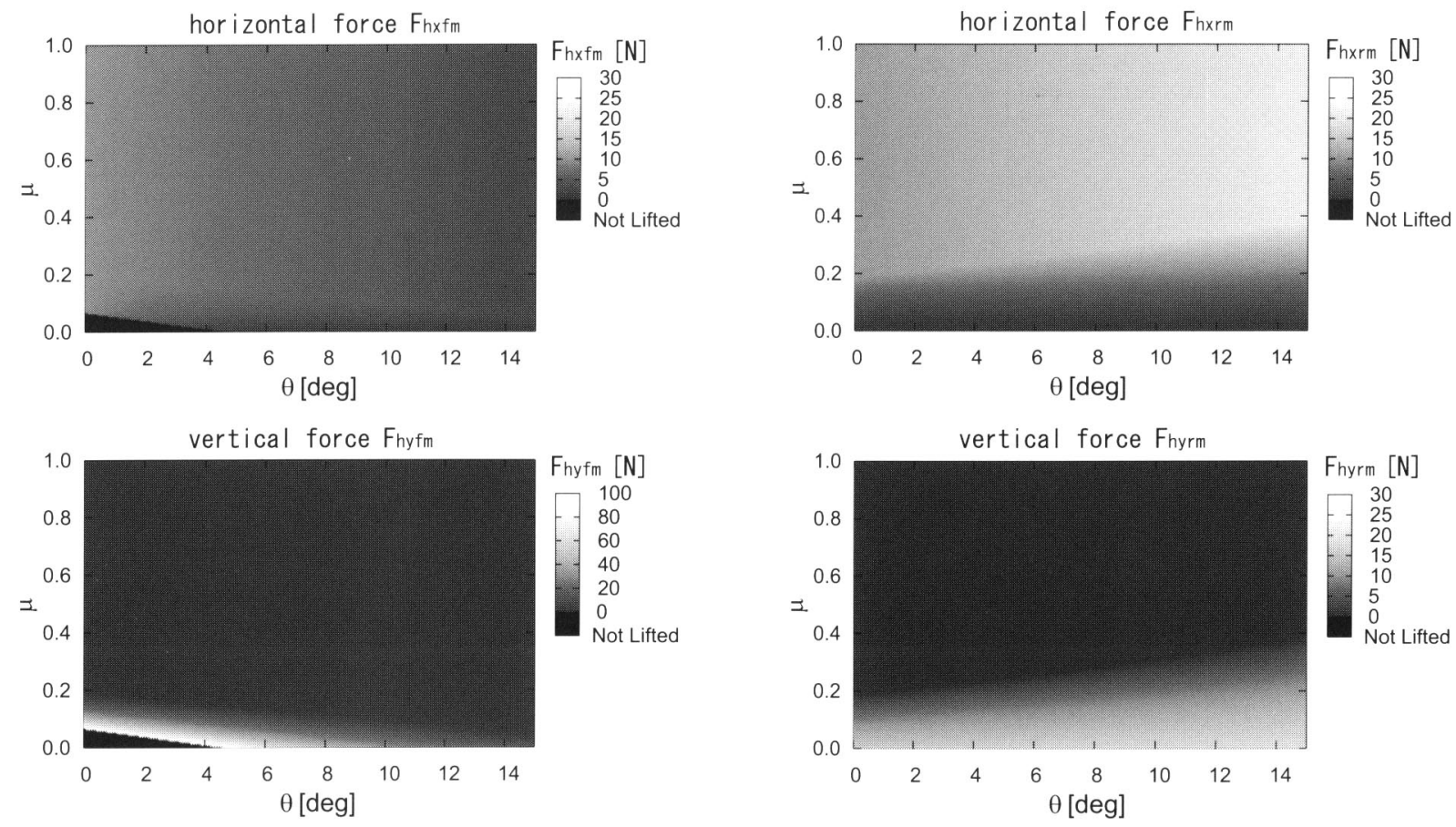

(a) 昇段時に前輪を持ち上げる動作

(a) Lift up front wheels during step mounting
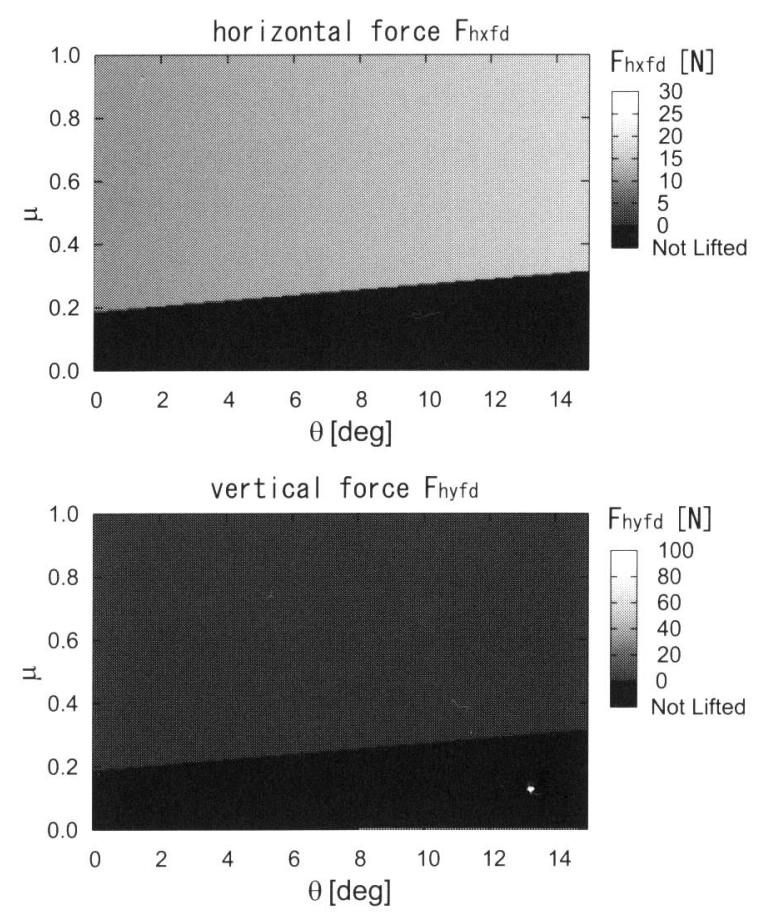

(c) 降段時に前輪を降ろす動作

(c) Lift down front wheels during step dismounting

(b) 昇段時に後輪を持ち上げる動作

(b) Lift up rear wheels during step mounting
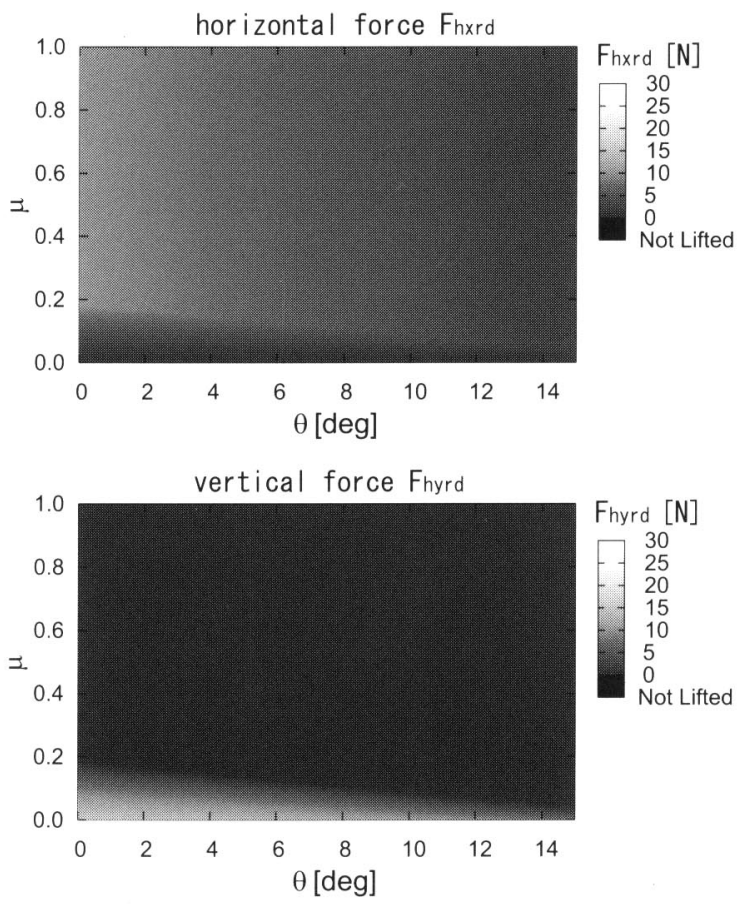

(d) 降段時に後輪を降ろす動作

(d) Lift down rear wheels during step dismounting

図 3 傾斜角 $\theta$ および静止摩擦係数 $\mu$ とハンドグリップに作用する力との関係. (a)〜 (d) には上下 2 つ図があるが，水平方向の力を上に，垂直方向の力を下に示す. 車輪を持ち上げたり降ろしたりする動作が，力学的に不可能な領域を黒色 (Not Lifted) で示す.

Fig. 3 Dependence of inclination angle $\theta$ and coefficient of static friction $\mu$ on force applied to handgrip. There are two figures in $(a) \sim(d)$. The upper side of $(a) \sim(d)$ is horizontal force, and the lower side is vertical force. It is impossible to lift up and down the wheels in the black area (Not Lifted). 


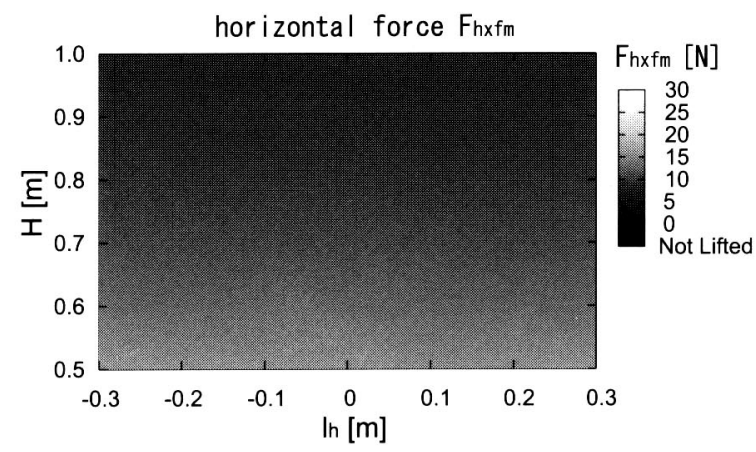

(a) 昇段時に前輪を持ち上げる動作

(a) Lift up front wheels during step mounting

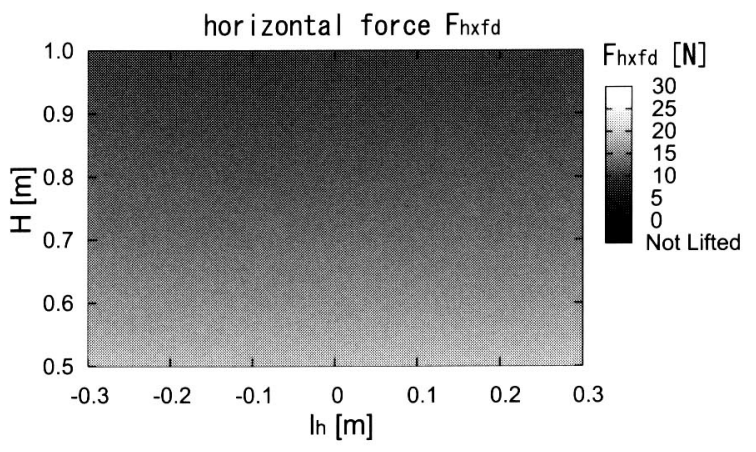

(b) 降段時に前輪を降乃す動作

(b) Lift down front wheels during step dismounting

図 4 傾斜角 $\theta=2.0[\mathrm{deg}]$ および制動装置使用時 $(\mu=0.8)$ のハンドグリップの高さ $H$ および後輪からの水平距離 $l_{h}$ とハンドグリップに作用する水平方向の力との 関係.

Fig. 4 Dependence of horizontal force applied to handgrip on height $H$ and horizontal distance from rear wheels $l_{h}$ of handgrip at an inclination angle $\theta=2.0$ [deg] with the use of a breaking system $(\mu=0.8)$.

後方に移動し， $F_{h y f m}$ のモーメントアーム長が長くなる ので， $\mu$ が小さくても前輪を持ち上げられる.

図 3(c) に示す降段時に前輪を降乃す動作については, 第一一第四すべてのケースが原因で, 前輪を降ろす動作 が不可能になることがあった。 後輪の真上にハンドグリッ プが配置されている $\left(l_{h}=0.0[\mathrm{~m}]\right)$ ので, 傾斜角 $\theta$ が小さ いと，ハンドグリップを引き上げる力 $F_{h y f_{d}}$ によるモー メントは小さい. 歩行補助車の重心に働く重力に対抗す るためには, ハンドグリップを手前に引くカ $F_{h x f_{d}}$ を大 きくする必要がある。しかし, $\mu$ が小さいと, 最大静止摩 擦力を超えてしまい, 後輪が動き出してしまうので, 後 輪を固定した状態で前輪を降ろす動作はできない.

\section{3-2. ハンドグリップの配置の分析}

傾斜角 $\theta$ と静止摩擦係数 $\mu$ の分析から, $\mu$ によって歩 行補助車の制御方法が变わること, $\mu$ の小さい領域では 前輪の操作が力学的に不可能になる場合があることがわ かった。この結果から， $\mu$ については，制動装置を使用 する場合と使用しない場合とを想定する．前者はすべり 摩擦となるため, 低速かつ路面が乾燥している状態での 報告に基づき $\mu=0.8$ とした7)。この值は, Finkelらが 四輪歩行車の座面に座る動作の危険性を検討するために 用いた，ブレーキをかけた車輪と路面との静止摩擦係数 と同程度である ${ }^{8)}$. 後者はころがり摩擦となるため, アス ファルト舗装路についての報告に基づき $\mu=0.01$ とし た ${ }^{9)}$. 傾斜角 $\theta$ については， $0.0[\mathrm{deg}]$ に設定すると車体 が傾くことで生じる項の影響が無視される，しかし，日 常生活で $\theta$ が大きくなるような状況も少ないと想定され る. 2005 年 2 月に改定された「歩道の一般的構造に関す
る基準」によると，歩道と車道との段差は，視覚障害者 の安全な進行を考慮して, $0.020[\mathrm{~m}]$ を標準とすることが 定められている ${ }^{10 !}$. 歩行補助車の奥行きを $0.59[\mathrm{~m}]$ と設 定したことから， $0.020[\mathrm{~m}]$ の段差を乗り越える場合を 想定して，傾斜角を $\theta=2.0[\mathrm{deg}]$ と設定する. ハンドグ リップの高さ $H$ の範囲を $0.5 \sim 1.0[\mathrm{~m}]$ とし，後輪から の水平距離 $l_{h}$ の範囲を $-0.30 \sim 0.30[\mathrm{~m}]$ とする. その他 の条件は，表 1 に示すとおりである.

制動装置を使用する $\mu=0.8$ の条件では，ハンドグリッ プをどこに配置しても，水平方向の力だけで，車輪を持 ち上げたり降ろしたりできる。図 4 に，前輪に関する動 作の結果を示す．前輪を持ち上げる動作も降ろす動作も， ハンドグリップをどこに配置しても，19.9[N] 以下の力 で車輪を操作できる，但し，図 1 や図 2 からわかるよj に，ハンドグリップ高 $H$ を高くすると，モーメントアー 厶長を長くできるので, 水平方向の力を小さくできる. 後 輪に関する動作についても，同様の結果が得られ，20.7 $[\mathrm{N}]$ 以下の力で車輪を操作できることがわかった.

制動装置を使用しない $\mu=0.01$ の条件では，車輪を操 作するために，水平方向だけでなく，垂直方向の力も八 ンドグリップヘ加える必要がある，特に前輪に関する動 作については，ハンドグリップの配置によっては，車輪

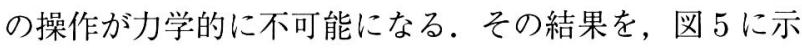
す．前輪を持ち上げる動作については，ハンドグリップ の高さが $H=0.5[\mathrm{~m}]$ であると, 後輪の後方 $0.055[\mathrm{~m}]$ $\left(l_{h}=-0.055\right)$ よりも，前方にハンドグリップを配置する と前輪を持ち上げられない，前輪を降ろす動作については， $H=0.5[\mathrm{~m}]$ であると, 後輪の前方 $0.159[\mathrm{~m}]\left(l_{h}=0.159\right)$ よりも，後方にハンドグリップを配置すると，後輪を固定 

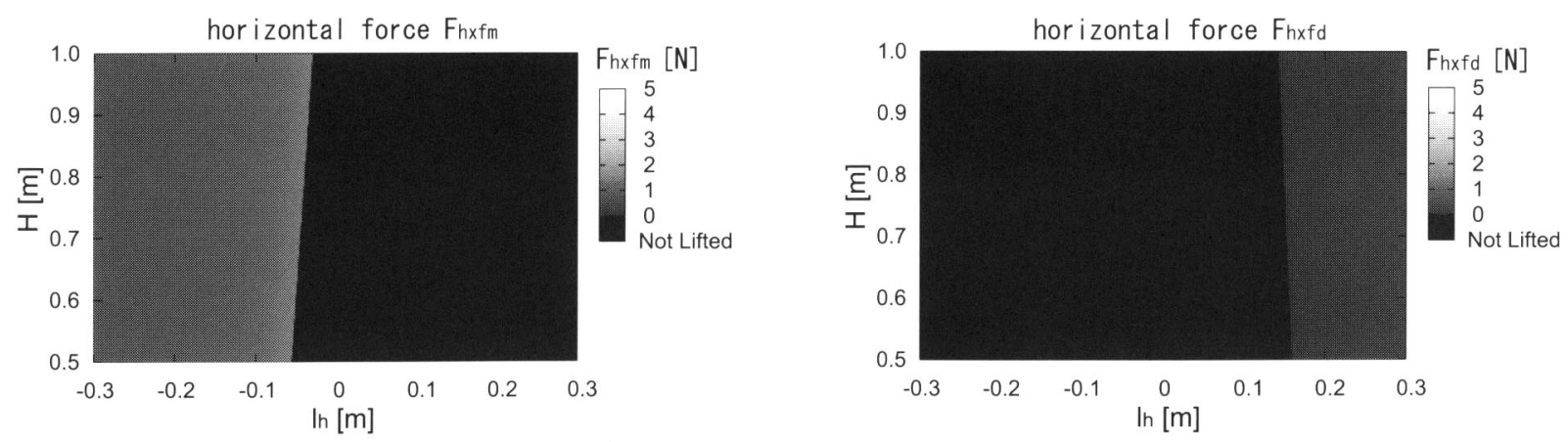

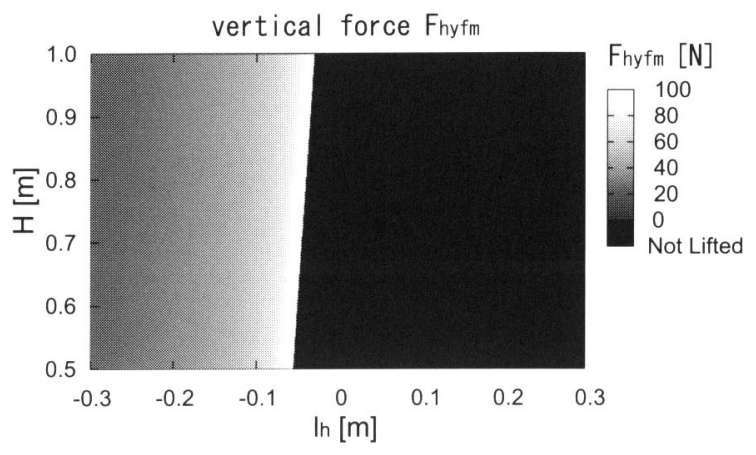

(a) 昇段時に前輪を持ち上げる動作

(a) Lift up front wheels during step mounting

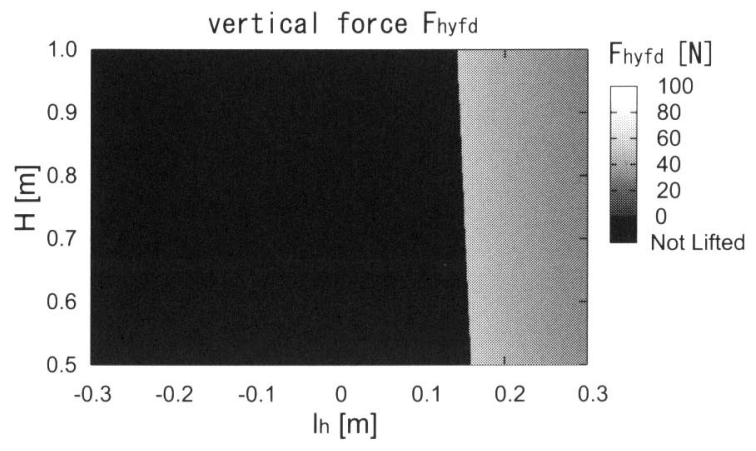

(b) 降段時に前輪を降ろす動作

(b) Lift down front wheels during step dismounting

図 5 傾斜角 $\theta=2.0$ [deg] および制動装置未使用時 $(\mu=0.01)$ のハンドグリップの高 さ $H$ 抢よび後輪からの水平距離 $l_{h}$ とハンドグリップに作用する力との関係. (a) と（b)には上下 2 つの図があるが, 水平方向の力を上に, 垂直方向の力を下に 示す．前輪を持ち上げたり降ろしたりする動作が，力学的に不可能な領域を黒色 (Not Lifted) で示す.

Fig. 5 Dependence of force applied to handgrip on height $H$ and horizontal distance from rear wheels $l_{h}$ of handgrip at an inclination angle $\theta=2.0$ [deg] without the use of a breaking system $(\mu=0.01)$. There are two figures in (a) and (b). The upper side of (a) and (b) is horizontal force, and the lower side is vertical force. It is impossible to lift up and down the front wheels in the black area (Not Lifted).

した状態では前輪を降ろせない. すなわち, $l_{h}=-0.055$ $0.159[\mathrm{~m}]$ にハンドグリップを配置する場合, 制動装置 を使用できないと，前輪を持ち上げたり降ろしたりする 動作が不可能になる場合がある。この原因は, 傾斜角と 静止摩擦係数の分析でも述べた, 前輪を持ち上げたり降 ろしたりする動作が力学的に不可能になる第一一第三の ケースである。

\section{3-3. カゴの配置の分析}

制動装置を使用しない場合の車輪の操作性は，ハンド グリップの配置により決まることがわかったため, カゴ の配置については，制動装置を使用する場合 $(\mu=0.8)$ の みを考える。傾斜角 $\theta$ については, ハンドグリップの配 置の分析と同様に $2.0[\mathrm{deg}]$ とする. カゴに積む荷物の質 量については，国民生活センターが実施したテストで用 いた荷物と同様に, $M=2.0[\mathrm{~kg}]$ とする ${ }^{2,3)}$. カゴの高さ $l_{b y}$ の範囲を $0.1 \sim 1.0[\mathrm{~m}]$ とし, 後輪からの水平距離 $l_{b x}$ の範囲を $0.00 〜 0.60[\mathrm{~m}]$ とする. その他の条件は, 表 1 に示すとおりである。

制動装置を使用する場合には， $2 \mathrm{~kg}$ の荷物を積んだ力 ゴをどこに配置しても，水平方向の力のみで車輪を操作 できる. 図 6 に分析の結果を示す.いずれの動作でも，力 ゴをどこに配置しても，25.9[N] 以下の力で車輪を操作 できる，車輪を操作する力は，カゴの水平方向の配置 $l_{b x}$ に依存し，高さ $H$ にはほとんど依存しない。これは，図 1 や図 2 からわかるように，カゴに積んだ荷物に由来す るモーメントのアーム長は, 傾斜角 $\theta$ が小さい領域では, そのほとんどが水平方向の配置 $l_{b x}$ により決まるためで ある。 


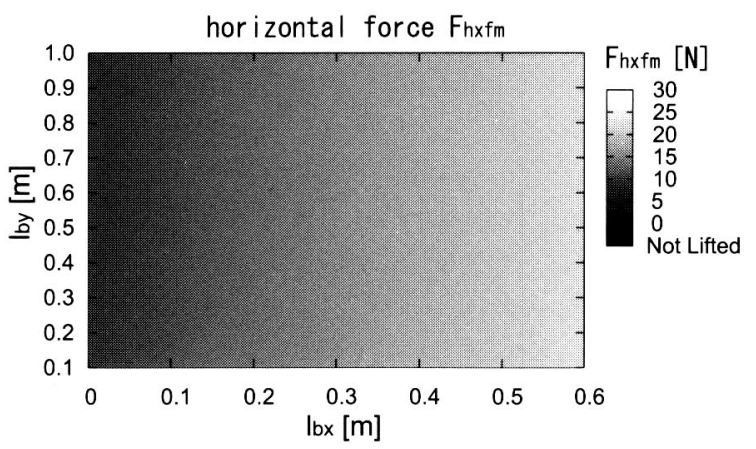

(a) 昇段時に前輪を持ち上げる動作

(a) Lift up front wheels during step mounting

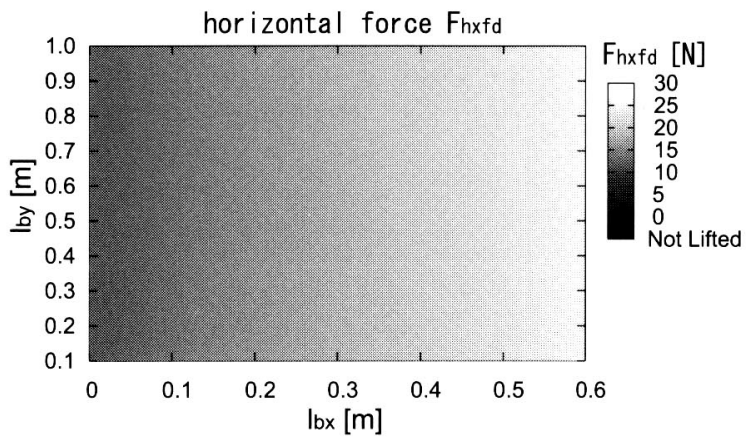

(c) 降段時に前輪を降乃す動作

(c) Lift down front wheels during step dismounting

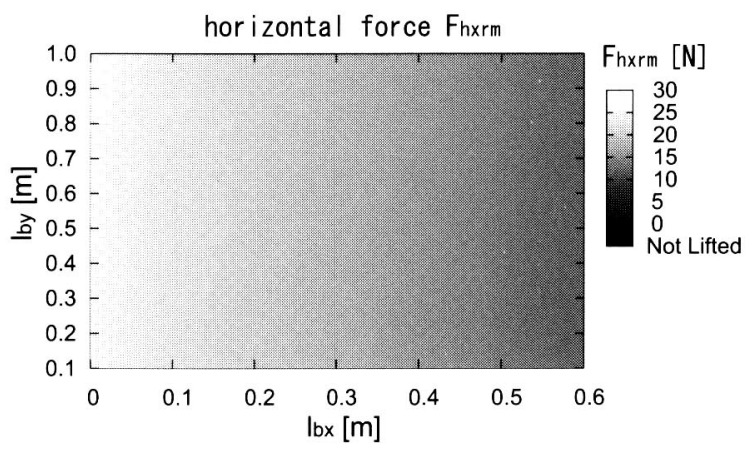

(b) 昇段時に後輪を持ち上げる動作

(b) Lift up rear wheels during step mounting

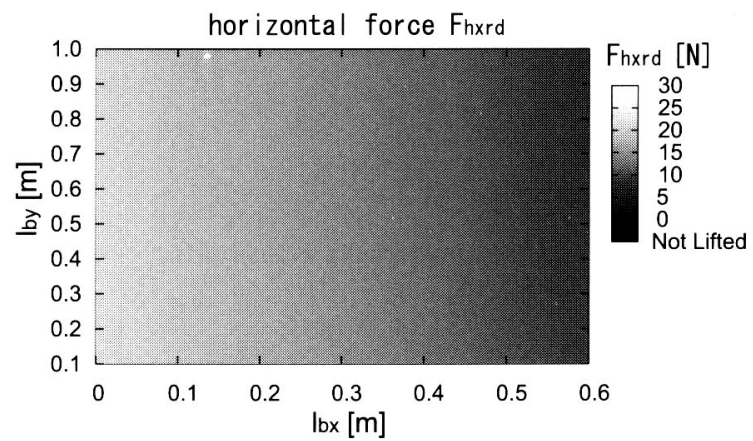

(d) 降段時に後輪を降乃す動作

(c) Lift down rear wheels during step dismounting

図 6 傾斜角 $\theta=2.0[\mathrm{deg}]$ および制動装置使用時 $(\mu=0.8)$ のカゴの高さ $l_{b y}$ および 後輪からの水平距離 $l_{b x}$ とハンドグリップに作用する水平方向の力との関係.

Fig. 6 Dependence of horizontal force applied to handgrip on height $l_{b y}$ and horizontal distance from rear wheels $l_{b x}$ of basket at an inclination angle $\theta=2.0[\mathrm{deg}]$ with the use of a breaking system $(\mu=0.8)$.

\section{4. 考 察}

歩行補助車の車輪を持ち上げたり降ろしたりする動作 を考慮する場合には，それらの動作の容易さと使用者の 支えとしての安定性とが問題になる．定常歩行のように すべての車輪が路面に接している動作では，4個の車輪 と使用者の両脚とで身体を支えるため, 基底面が広くな り，使用者の姿勢の安定性も増す。しかし車輪を持ち上 げたり降ろしたりする動作では，前輪または後輪のいず れかが路面を離れ，接地している 2 個の車輪と使用者の 両脚とだけで身体を支えている状態となる。この状態は, 基底面が狭く, 力学的に不安定で, 姿勢の安定性も低い. 筋力や平衡性などの使用者の行動体力が高く ${ }^{11)}$, 車輪を 持ち上げたり降ろしたりする動作が容易であれば，使用 者は素早く段差を乗り越えることができ，身体への負担 も小さい. しかし，行動体力が低く車輪を持ち上げたり 降ろしたりする動作が困難な場合, 使用者は基底面が狭 く不安定な姿勢に長く曝されることになり, 身体への負
担も増加する。したがって，車輪を持ち上げたり降ろし たりする動作を容易にすることが，使用者の姿勢の安定 性の向上にも繋がる。そのため，力学モデルを用いた理 論的な分析の結果をもとに，制動装置の使用の影響と八 ンドグリップやカゴの配置の影響とについて考察する.

図 3 からわかるように, 車輪と路面との静止摩擦係数 $\mu$ により，使用者が取るべき歩行補助車の制御方法が変 わる。 $\mu$ が 0.4 以上あれば，ハンドグリップに水平方向 の力を加えるだけで車輪を操作できる，その力は，最大 でも $21.1[\mathrm{~N}]$ あれば良い， $\mu$ を決める要因は様々あるが， 人間工学的な要因としては，ハンドブレーキなどの制動 装置がある。制動装置で車輪の回転を止められれば，車 輪と路面との間はすべり摩擦となる. 自動車技術会によ ると, 低速で路面が乾燥している状態での夕イヤのすべ り摩擦係数は $0.7 \sim 0.9$ 程度, 濡れている状態でも 0.5

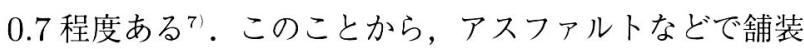
された路面で，制動装置を適切に使用すれば，使用者は ハンドグリップを手前に引いたり奥へ押したりするだけ で，容易に車輪を操作できる。但し，この条件を満たし 
ていても，ある環境になると，水平方向の力だけでは歩 行補助車を制御できなくなる場合もある。そのひとつは, 路面が氷や雪で覆われている環境である. 水または雪で 覆われていると， $\mu$ はそれぞれ $0.05 〜 0.25$ または $0.10 〜$ 0.60 まで低下する ${ }^{9)}$.この環境下では, 水平方向の力た けでは歩行補助車を制御できないので, 垂直方向の力を 加える必要がある. しかし, 歩行補助車のユーザである 高齢者の行動体力を考慮すると, 路面が氷や雪で覆われ た環境での使用は避けるべきである。その他の環境とし ては, 一般の歩道や交差点での横断歩道などにあるマン ホールの蓋や排水用のグレーチングがある。これらの素 材は，ほとんどがスチールやステンレスなどの金属であ る. 自動車技術会によると, 路面が金網の場合のすべり 摩擦係数は, 乾いていると $0.70 \sim 0.90$ であるので, 車輪 の操作に支障はない9). しかし濡れていると, すべり摩擦 係数が $0.25 \sim 0.45$ まで低下するので, 水平方向の力だけ では車輪を操作できない可能性がある. したがって, 路面 が濡れた環境下で，金属製のマンホールの蓋やグレーチ ングの上での昇段動作や降段動作は, 避けるべきである.

静止摩擦係数 $\mu$ が 0.4 未満であると, 水平方向だけで なく, 垂直方向の力をハンドグリップヘ加えないと, 車 輪を操作できない場合がある. 特に, 前輪に関する動作 については, 図 5 に示すように, 前輪の操作が力学的に 不可能になる場合がある。この問題は, 制動装置を使用 して $\mu$ を 0.4 以上にすれば回避できる。しかし，市販の 多くの歩行補助車は, 4 個の車輪すべてに制動装置を備 えていない. 例えば，制動装置が後輪だけにある場合は, 前輪を制動できないので, 後輪を昇段時に持ち上げる動 作や降段時に降乃す動作が困難となる．使用者が意図し たように昇段動作や降段動作ができるように，すべての 車輪に制動装置を備えることが望ましい.

制動装置を使用すれば，図 4 からわかるように，ハン ドグリップをどこに配置しても，20.7 [N] 以下の力で車 輪を操作できる。また図 6 からわかるように， $2 \mathrm{~kg}$ の荷 物を積んだカゴをどこに配置しても，25.9 [N] 以下の力 で車輪を操作できる。この結果から, 昇段および降段動 作を考慮する場合には, 動作中に制動装置を適切に使用 できるような機能を, 歩行補助車に備える設計が重要で あることがわかる. 市販の歩行補助車の主要な制動装置 は, ハンドブレーキと車輪をロックするストッパ機構で ある、ハンドブレーキは，自転車や自動二輪車のそれと 同様に，ハンドグリップの前にレバーが取り付けられて おり，レバーを握ることで車輪を制動するような仕組み になっている，ストッパ機構は，駐車時に用いられるもの で，ハンドグリップと離れた場所に設置されている．使
用者が専用のレバーなどを操作して，車輪を強制的に回 転できなくする仕組みである，昇段や降段の動作をする 際に，使用者はハンドグリップを握りながら歩行補助車 を操作する。したがって，ハンドブレーキが，それらの 動作を容易にする仕組みとして適している．市販の歩行 補助車には，一体式や分離式のハンドブレーキがあるが, いずれもレバーを握る仕組みとなっている．車輪をしっ かりと制動するためには，使用者がハンドグリップとレ バーとをしっかりと握りしめられるような構造にしなけ ればならない. 人間生活工学研究センターが, 握りやす い太さに関する調査を行っている ${ }^{12)}$ 。 その調査では, 分 離式ハンドグリップのような矢状面に平行な握りと，一 体式ハンドグリップのような前額面に平行な握りとにつ いて，握りやすい太さや握りにくくなる太さについて調 べている．身体をあずけるような握りと持って動かすよ うな握りのいずれの場合でも，いずれの方向に握っても， 直径 30～40mm が握りやすい太さであり，10mm 以下や $60 \mathrm{~mm}$ 以上の太さだと握りにくくなる．また，高齢者は 若年者に比べて, 握りにくくなる太さの上限值が細くな る傾向がある. そのため, $60 \mathrm{~mm}$ 未満の距離で握りしめ られるようなハンドブレーキの構造に設計するのが望ま しい.

ハンドグリップの配置については，昇段および降段動 作だけでなく, 歩行補助の機能についても考慮する必要 がある．昇段および降段動作だけを考慮するのであれば, 図 4 からわかるように，制動装置を適切に使用すれば， ハンドグリップをどこに配置しても良い.しかし，ハン ドグリップを前や後に配置しすぎると，歩行動作を妨げ， 上や下に配置しすぎても，歩行補助の機能を果たさない. また, 使用者である高齢者の体格や行動体力も一様でな い. そのため, ハンドグリップの高さについては, 市販の 歩行補助車のほとんどに備わっている機能であるが, 使 用者の使いやすい高さに設定できるようにすることが望 ましい. 但し, 図 4 からわかるように, 水平方向の力に よるモーメントを大きくできるので，ハンドグリップの 高いほうが, 昇段動作や降段動作は容易になる。次に，具 備されている歩行補助車は少ないが，ハンドグリップの 水平方向の配置についても，使用者の使いやすい位置に 設定できることが望ましい，図 4 からわかるように，制 動装置を適切に使用すれば, 水平方向の配置は, 車輪を 持ち上げたり降ろしたりする動作にほとんど影響しない. 行動体力の高い高齢者であれば，歩行動作を妨げないよ うに，ハンドグリップを後輪の近傍に配置するのが望ま しい. しかし, 行動体力の低い高齢者の中には, ハンド グリップ部分全体に上体をもたれかけて押している場合 
もある ${ }^{13)}$.このような使用者に対しては, 歩行中の安定 性を高めるため，ハンドグリップを後輪よりも前方に配 置するのが望ましい.

カゴについては, 図 6 からわかるように, 水平方向の 配置が重要である．前に配置すると荷物を積んだ際に前 輪を操作する労力が大きくなり, 後に配置すると後輪を 操作する労力が大きくなる．したがって, 水平方向の配置 については，前輪と後輪との中間付近とすることが望ま しい.この設計方針は，歩行補助や休息の機能と矛盾し ない．前輪と後輪との中間付近にカゴを配置すれば，使 用者の歩行動作を妨げる可能性は低い．また，カゴに積 んだ荷物に作用する重力を前後輪に均等に配分できるの で，歩行中の安定性も確保できる，さらに，カゴの蓋は 休息の際に使用者が座る座面として使用されることが多 い．座面が前方や後方に配置されていると，座る際に使 用者が加える体重などの力により，歩行補助車が転倒す る危険がある．Eblen らは，座面に座る動作の安全性に 関して, 歩行補助車の重心位置と座面の水平方向の配置 はトレードオフの関係にあることを報告している8 し，前輪と後輪との中間付近に座面となるカゴを配置す れば，休息時の転倒リスクを軽減した上で，歩行時や荷 物運搬時の安定性も確保することが可能である．カゴの 高さについては，水平方向の配置ほどの制約はない。し かし, 歩行補助の観点からは, 高すぎると安定性を損な うので望ましくない．また，休息の観点からは，座面の 高さに適した位置に，カゴの蓋を配置する必要がある.

\section{5. まとめ}

歩行補助車の車輪を段の上へ持ち上げたり段の下へ降 ろしたりする際に，使用者がハンドグリップヘ加える力 を推定した。さらに，制動装置の使用の影響，および八 ンドグリップやカゴの配置の影響について理論的に分析 した。その結果，次の 4 項目を明らかにした。

1. 昇段および降段動作を容易にするためには, 動作中 に車輪を適切に制動できるような機能を，歩行補助 車に備える設計が重要である。そのように設計すれ ば，ハンドグリップを手前に引いたり奥へ押したり する水平方向の力だけで，車輪を容易に操作できる，

2. 制動装置を使用できないと, 水平方向だけでなく, 垂 直方向の力をハンドグリップヘ加えないと車輪を操 作できない場合がある．特に，前輪に関する動作に ついては，ハンドグリップの配置によっては，車輪
の操作が力学的に不可能になる場合がある.

3. 昇段および降段動作に関しては，制動装置を適切に 使用できるよう設計すれば，ハンドグリップをどこ に配置しても良い. しかし, 歩行補助の機能を最大限 に発揮できるように，使用者の体格や行動体力を考 慮して，ハンドグリップの配置を決める必要がある。 4. カゴの水平方向の配置については, 前輪と後輪との 中間に配置するのが望ましい。

以上の研究成果は, 人間工学的な観点から歩行補助車 を設計する際の基本的な手段を与える。しかし，現実の 使用状況を考慮すると，分析に取り込むべき人間工学的 な要因が，いくつか残されている. 例えば，ハンドブレー キで前輪を制動しながら後輪を持ち上げる場合に，最後 に制動を微妙にゆるめて歩行補助車全体をわずかに前進 させないと昇段動作が完結しないことなどである．本研 究の成果をもとに，各種の要因を取り入れ，より現実に 即した分析をすることが今後の課題である。

\section{参考文献}

1）製品安全協会：CPSA0075 歩行補助車の認定基準及び 基準確認方法, 1 14, 製品安全協会, 2000 .

2）国民生活センター: 歩行補助車の安全を考える, $5 \sim 13$, 国民生活センター, 2003.

3）国民生活センター：歩行補助車をテスト，たしかな目， 200, 68 74, 2003.

4) C. Eblen \& J. Koeneman: A multidimensional evaluation of a four-wheeled walker, Assistive Technology, 3(1), 32-37, 1991.

5）テクノエイド協会：福祉用具総覧 $2004,158 \sim 167$ ，テ クノエイド協会, 2004 .

6）製品評価技術基盤機構：人間特性データベース 最大発 揮力デー夕

7）自動車技術会：新編・自動車工学ハンドブック，6-1, 図 書出版, 1970.

8) J. Finkel, G. Fernie \& W. Cleghorn: A guideline for the design of a four-wheeled walker, Assistive Technology, 9(2), 116 129, 1997.

9）自動車技術会：新編・自動車工学ハンドブック，3-1 $3-5$, 図書出版, 1970.

10）国土交通省道路局，都市・地域整備局：歩道の一般的 構造に関する基準，1３，国土交通省，2005.

11）琉子友男：高齢者の体力と転倒，眞野行生，高齢者の 転倒とその対策，25３2，1999.

12）人間生活工学研究センター: 高齢者対応基盤整備研究開 発 第 II 編 データベース整備 (動態・視聴覚特性), 140 150 , 人間生活工学研究センター, 2001.

13）堀内邦雄，青木和夫：シルバーカーを押す力の測定，人 間工学, 39(1), 38〜41, 2003. 